\title{
'It's just so much waste.' A qualitative investigation of food waste in a universal free School Breakfast Program
}

\author{
Stacy A Blondin*, Holly Carmichael Diang, Nesly Metayer, Stephanie Anzman-Frasca and \\ Christina D Economos \\ Friedman School of Nutrition Science and Policy, Tufts University, 150 Harrison Avenue, Boston, MA 021 11, USA
}

Submitted 21 March 2014: Final revision received 31 October 2014: Accepted 10 November 2014: First published online 29 December 2014

\begin{abstract}
Objective: To understand stakeholders' perspectives on food waste in a universal free School Breakfast Program implementing a Breakfast in the Classroom model. Design: Semi-structured focus groups and interviews were conducted with school district stakeholders. Inductive methods were used to code resulting transcripts, from which themes were identified. The analysis provides a thematic analysis of stakeholders' perspectives on food waste in the School Breakfast Program.

Setting: Ten elementary schools in a large urban school district implementing a universal free Breakfast in the Classroom model of the US national School Breakfast Program.

Subjects: Elementary-school students ( $n$ 85), parents ( $n$ 86), teachers $(n$ 44), cafeteria managers ( $n$ 10) and school principals ( $n$ 10).

Results: Stakeholders perceived food waste as a problem and expressed concern regarding the amount of food wasted. Explanations reported for food waste included food-related (palatability and accessibility), child-related (taste preferences and satiation) and programme-related (duration, food service policies, and coordination) factors. Milk and fruit were perceived as foods particularly susceptible to waste. Several food waste mitigation strategies were identified by participants: saving food for later, actively encouraging children's consumption, assisting children with foods during mealtime, increasing staff support, serving smaller portion sizes, and composting and donating uneaten food.

Conclusions: Stakeholders recognized food waste as a problem, reported myriad contributing factors, and have considered and employed multiple and diverse mitigation strategies. Changes to the menu and/or implementation logistics, as well as efforts to use leftover food productively, may be possible strategies of reducing waste and improving the School Breakfast Program's economic, environmental and nutritional impact.
\end{abstract}

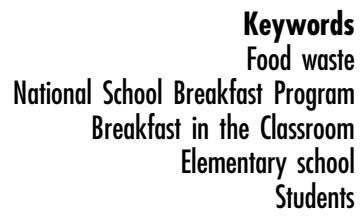

\section{Food waste in US school meal programmes}

An estimated $31 \%$ of food is wasted annually in the USA at the retail and consumer levels ${ }^{(1)}$. This translates into approximately \$US 162 billion annually and $5230 \mathrm{~kJ}$ $(1250 \mathrm{kcal}) /$ person per $\mathrm{d}$. The term 'food waste', as defined by the US Department of Agriculture, refers to any unconsumed edible item, including retailer and consumer disposal $^{(1)}$. Wasted food has immense and deleterious implications for people, the economy and the environment ${ }^{(2)}$. With regard to the latter, food waste contributes to avoidable greenhouse gas emissions and resource utilization (water, labour, land, fossil fuels, fertilizer, etc.), which threaten food system sustainability and food security via environmental degradation, biodiversity reduction and climate change ${ }^{(3)}$. It is estimated that reducing food waste in the USA by a mere $15 \%$ could feed an additional 25 million people ${ }^{(4)}$.
US public schools, which serve 7.4 billion meals to more than 30 million children ${ }^{(5,6)}$, represent a prime target for food waste reduction. The National School Lunch Program (NSLP) and School Breakfast Program (SBP) are intended to reduce food insecurity and malnutrition among 'nutritionally needy children' by providing nutritious meals ${ }^{(7)}$. Food waste in these programmes undermines such goals by increasing children's short- and long-term risk of food insecurity, hunger and/or nutrient deficiencies ${ }^{(8)}$. Food insecurity is associated with poor diet quality and increased risk for obesity ${ }^{(9-14)}$. Recognizing these perils and the resource constraints schools face in addressing food waste, the US Department of Agriculture and US Environmental Protection Agency launched the US Food Waste Challenge in 2013, specifying school meal programme food waste reduction as one of the five campaign priorities ${ }^{(15)}$. 
Previous research suggests that food waste in US public schools is substantial in magnitude and value ${ }^{(8,16,17)}$. The NSLP has been the subject of the majority of related studies $^{(16,18-28)}$. Comparatively little research has considered food waste in the SBP. The School Breakfast Program Pilot Project (SBPP) compared six school districts randomized to a universal free SBP treatment condition with matched control districts operating under a traditional three-tiered meal pricing structure (full, reduced, free) over a 3-year period ${ }^{(29,30)}$. Treatment schools served breakfast in either the classroom or cafeteria. At the end of the first and third years, a greater proportion of cafeteria managers in treatment schools reported an increase in plate waste compared with control schools. Furthermore, among treatment schools, a greater proportion of cafeteria managers serving Breakfast in the Classroom (BIC) reported an increase in plate waste compared with those serving breakfast in the cafeteria. Treatment schools reporting a decline in plate waste in the final year only included those serving breakfast in the cafeteria. In a regional study in Milwaukee, WI, the quantity of food waste in a universal free BIC model of the SBP was observed, revealing that about half ( $52 \%$ ) of selected food items were fully consumed and that younger children disposed of greater quantities of food than older children $^{(31)}$. These studies provide evidence of food waste within the SBP, but neither explored stakeholders' perspectives about the waste.

As SBP participation continues to increase ${ }^{(32)}$, and universal free school meal programmes expand ${ }^{(33,34)}$, total food waste in such programmes is expected to rise concomitantly. In light of this anticipated growth, identifying effective waste mitigation strategies has tremendous preventive potential. Yet no studies have thoroughly investigated diverse stakeholders' perceptions of, attitudes towards or reactions to food waste in the SBP. In order to identify and implement efficient and effective mitigation strategies, consideration of the school community's perspectives is imperative. Therefore, the aim of the present study was to investigate stakeholder perspectives on food waste, including causes and mitigation strategies and suggestions, in the universal free SBP implementing a BIC delivery model.

\section{Methods}

\section{Sample}

Ten demographically representative public elementary schools were recruited from a large, urban school district in the USA. These schools had implemented the BIC delivery model for 3-6 months prior to recruitment. They had previously served universal free breakfast to all students in the cafeteria before the start of the school day. All schools participating in the SBP must offer four food items, at least one from each of three meal components (grain, fruit/juice/ vegetable and milk). Under the offer versus serve (OVS) policy that was in place during the present study (20122013), a service model intended to reduce food waste, students were permitted to refuse any one meal item without compromising reimbursement eligibility ${ }^{(35,36)}$.

Parent-student dyads, teachers, principals and cafeteria managers were recruited to participate. Twenty-nine focus groups (ten parent, five teacher and fourteen student groups) and twenty interviews (ten cafeteria managers, ten principals) were conducted. Cafeteria managers from each school ( $n$ 10) were recruited directly by participating principals ( $n$ 10), while teachers ( $n$ 44) and parentstudent dyads ( $n$ 86) were recruited for focus groups in five of the schools by flyer. The average number of participants per focus group was nine for parent groups, six for student groups and nine for teachers. Five of the ten parent groups were conducted in Spanish by a Spanishspeaking moderator. Focus groups and interviews did not exceed $45 \mathrm{~min}$ for children and $60 \mathrm{~min}$ for adults.

Eligible parents had a child enrolled in grades $\mathrm{K}-5$ in one of these schools, permitted their child to participate in a student focus group, and spoke English or Spanish. Adults received a $\$$ US 50 gift card and students received a small gift (valued at $\leq \$$ US 5) for participating. The study was conducted according to the guidelines laid down in the Declaration of Helsinki, and all procedures involving human subjects were approved by the Tufts University Institutional Review Board and by the school district's Committee for External Research Review Chair. Written and/or verbal informed consent was obtained from all adult participants and informed assent was obtained from children.

\section{Data collection}

\section{Instrument development}

Semi-structured focus group and key informant interview guides were developed for each participant group via an iterative process. Each guide consisted of three topic areas with supporting questions, sub-questions and probes. The number of questions per topic area ranged from three to seven, for a total of eleven to fifteen questions per guide (mean: 12.4). Questions pertained to morning routines and breakfast consumption patterns at home and at school, programme rollout and implementation, and opinions and feelings about BIC. Questions were open-ended and reflected researcher-identified key topic areas derived from familiarity with existing school breakfast-related literature $e^{(5,29,37-44)}$, first-hand observations of the programme in the district and around the country, and meetings with district and programme partners. Instruments underwent further refinement following pilot testing with ChildObesity 180 staff and children participating in the BIC SNP in Somerville, MA. Table 1 provides sample questions that asked directly about food waste and/or that elicited food waste-related responses. A brief demographic questionnaire requesting information on age, gender, ethnicity and employment was administered to adult participants at the start of each 
Table 1 Focus group and interview guide prompts eliciting food waste-related responses

\begin{tabular}{|c|c|c|}
\hline Participant group & Main question or prompt & Sub-questions (probes) \\
\hline Teachers & $\begin{array}{l}\text { 1. Tell us about students' consumption of the breakfast foods provided } \\
\text { to them } \\
\text { 2. Some children may choose to not eat all of the breakfast provided to } \\
\text { them. Talk about children saving food or trading with others in your } \\
\text { classroom }\end{array}$ & $\begin{array}{l}\text { 1. What foods do your students tend to usually eat? Why do you think this is? } \\
\text { What foods most often end up in the trash? Why do you think this is? Think } \\
\text { about the overall classroom. Describe how much food is generally eaten and } \\
\text { how much is thrown away } \\
\text { 2. What types of food items are saved for later? What do they usually do with } \\
\text { those food items? If they eat their saved food items later, when do they } \\
\text { usually eat them? }\end{array}$ \\
\hline Cafeteria managers & $\begin{array}{l}\text { 1. What other changes have you noticed at the school since BIC began? } \\
\text { 2. Please describe your experience implementing the BIC programme } \\
\text { 3. Describe the ways serving BIC differs from serving it in the cafeteria } \\
\text { 4. In the course of daily operation of BIC, what is the most challenging } \\
\text { aspect of running the programme? }\end{array}$ & $\begin{array}{l}\text { 1. (Meal quality, budget, food waste) } \\
\text { 2. What was the biggest barrier or challenge you faced in implementing the } \\
\text { programme? } \\
\text { 3. What do you feel has changed the most? (Staffing, time to prep, clean-up) } \\
\text { 4. Are these challenges the same as those you experienced when breakfast } \\
\text { was served in the cafeteria? If not, what's different? }\end{array}$ \\
\hline Principals & $\begin{array}{l}\text { 1. Please describe your overall experience implementing BIC at your school } \\
\text { 2. What other changes have you noticed at the school since BIC began? }\end{array}$ & $\begin{array}{l}\text { 1. What barriers or challenges have you encountered? Are these challenges } \\
\text { the same as those you experienced when breakfast was served in the } \\
\text { cafeteria? If not, what's different? } \\
\text { 2. (Overall attitude of students/staff, scheduling, food waste) }\end{array}$ \\
\hline Parents & $\begin{array}{l}\text { 1. Now think about what typically happens once your child gets to school } \\
\text { 2. What are reasons that children might eat or drink something before } \\
\text { school and also eat BIC? } \\
\text { 3. What do you like least about the BIC programme? } \\
\text { 4. What changes, if any, would you suggest/recommend to improve the BIC } \\
\text { programme as a whole? }\end{array}$ & $\begin{array}{l}\text { 1. To the best of your knowledge, what does your child eat or drink during BIC? } \\
\text { 2. (Hungry upon waking, doesn't care for BIC food, etc.) }\end{array}$ \\
\hline Students & $\begin{array}{l}\text { 1. When you get to school, do you feel hungry? How hungry do you feel? } \\
\text { 2. Do you eat or drink anything during BIC? } \\
\text { 3. How do you feel after eating BIC? } \\
\text { 4. What do you do with BIC foods that you don't finish? }\end{array}$ & $\begin{array}{l}\text { 1. (Very hungry, not hungry, sort of hungry) } \\
\text { 2. If so, what? } \\
\text { 3. Do you still feel hungry? Do you feel full? Or do you feel just right? } \\
\text { 4. Do you save food for later? Which foods do you like to save? Do you trade it } \\
\text { or give it to other students? Do you throw it away? Do you take it home? }\end{array}$ \\
\hline
\end{tabular}

BIC, Breakfast in the Classroom 
interview/focus group. Questionnaires were not administered to children. Parent focus group guides and demographic questionnaires were translated into Spanish for use in Spanish-speaking groups.

\section{Logistics}

Research staff were recruited and trained on study protocols prior to data collection in 2013. Adult participants completed anonymous demographic questionnaires prior to verbal discussions. All dialogue was recorded, with the exception of one Spanish-speaking focus group (due to recorder failure). A moderator facilitated each focus group and a district employee attended student focus groups to monitor adherence to district-specific child protection rules. Parent and student focus groups were scheduled synchronously, with child care provided for nonparticipating children. Grade-specific (K-2/3-5) student focus groups were conducted in English; gender was observed and recorded. Parent groups were offered in Spanish (with a Spanish-speaking moderator and notetaker) and English. Notes and observations were documented by at least one researcher during each session. Research personnel summarized responses aloud to participants during each session and debriefed as a group afterwards to corroborate results.

\section{Data analysis}

NVivo qualitative data analysis software version 10 was used to conduct all analyses. Audio recordings were transcribed into Spanish then translated into English. Subsequently, the lead researchers and an external analyst developed a preliminary codebook via line-by-line text coding of one transcript for each respondent group. Six trained analysts then established inter-rater reliability with a senior analyst $(\geq 80 \%$ agreement) on three randomly selected transcripts. During subsequent independent coding of all transcripts, open coding permitted the incorporation of latent codes ${ }^{(45)}$. Inductive thematic analysis was used to identify implicit and explicit themes within codes to describe and organize like responses and understand underlying phenomena ${ }^{(46)}$. These themes were independently identified by two analysts; results were compared and discrepancies discussed until mutual agreement was reached. Notes and observations made during data collection were then cross-referenced. Narrative summaries of the themes identified within each code were drafted, which were discussed with the analysis team and reviewed by the lead analysts. Based on these findings, three overarching themes were identified related to food waste (Fig. 1), primarily from within the code labelled 'what is discarded and why and unfavourable items'.

\section{Results}

\section{Sample}

Two hundred and thirty-five unique voices were recorded in the focus groups and interview sessions. Although analyses were not stratified, no differences or patterns in responses by school or focus group language were apparent. Some but not all parent participants had volunteered in or otherwise observed BIC. Table 2 provides a sociodemographic profile of study participants. Briefly, parents, students and cafeteria managers were predominantly Hispanic (>70\%), whereas the majority of principals and teachers $(60 \%$ and $57 \%$, respectively) were non-Hispanic. The majority of adults were aged less than 65 years, and students were in grades K-5 (approximately 5-11 years of age). Parents, teachers and food service managers were predominantly female (>80\%), while the gender division of principals and students was more equitable. Approximately half (53\%) of parents preferred Spanish.

\section{Focus groups and interview findings}

Three overarching themes were identified: (i) participant perceptions and attitudes towards food waste; (ii) explanations for food waste; and (iii) strategies to mitigate food waste. Figure 1 provides an outline of these themes and sub-themes, and Table 3 provides a selection of corresponding quotes.

\section{Perceptions and attitudes towards food waste}

Perceptions and attitudes towards food waste were expressed by adult focus group and interview participants (parents and school staff) and pertained to estimated quantities of waste and to personal sentiments (emotions and attitudes) surrounding food waste. While comments related to food waste were generally negative, some positive comparisons were made between cafeteria- and classroom-based breakfast.

\section{Quantity}

Stakeholders held varying perceptions of the amount of food waste generated, depending in part on their perspective.

Relative. With regard to the quantity of food wasted in the BIC delivery model of SBP compared with the previous traditional model of SBP served in the cafeteria, participants generally agreed that waste per programme participant had decreased. For example, one classroom parent volunteer remarked: 'Yeah. I don't see as much of the food items being tossed at breakfast...'. A cafeteria manager agreed: 'I would say at breakfast, at least there's less waste - kids are not throwing their trays away automatically like they did, because they want[ed] to go out and play on the yard.'

Absolute. However, others noted that increased participation rates resulted in overall increases in the total amount waste. A parent considering the effects of increased programme scale confirmed: '... There's so much waste. ... Multiply by one classroom times the 28 classrooms or however many classes we have, it's wretched...'. Others recognized that the total amount of waste varied considerably by grade level and menu offerings. Regardless, the total quantity of waste was underscored by participants 
Table 2 Participant characteristics by group: stakeholders (principals, cafeteria managers, teachers, parents and students) from ten elementary schools in a large urban US school district implementing a universal free Breakfast in the Classroom model of the School Breakfast Program

\begin{tabular}{|c|c|c|c|c|c|}
\hline \multirow[b]{2}{*}{ Variable } & \multicolumn{5}{|c|}{ Respondent group } \\
\hline & Principals & Cafeteria managers & Teachers & Parents & Students \\
\hline$n$ & 10 & 10 & 44 & 86 & 85 \\
\hline \multicolumn{6}{|l|}{ Age (years) ${ }^{\star}$} \\
\hline $25-44(\%)$ & 50 & 40 & 59 & 76 & - \\
\hline 45-64 (\%) & 50 & 60 & 32 & 21 & - \\
\hline$\geq 65(\%)$ & 0 & 0 & 9 & 1 & - \\
\hline \multicolumn{6}{|l|}{ Gender } \\
\hline Female (\%) & 60 & 90 & 82 & 91 & 57 \\
\hline \multicolumn{6}{|l|}{ Ethnicity† } \\
\hline Hispanic (\%) & 40 & 90 & 43 & 77 & $\sim 73$ \\
\hline Non-Hispanic (\%) & 60 & 10 & 57 & 20 & $\sim 27$ \\
\hline \multicolumn{6}{|l|}{ Grade levelł } \\
\hline $\mathrm{K}-2(\%)$ & - & - & 52 & - & 33 \\
\hline $3-5(\%)$ & - & - & 50 & - & 67 \\
\hline \multicolumn{6}{|c|}{ Years at current school } \\
\hline Mean & 3.5 & 4.6 & 11.8 & - & - \\
\hline SD & $2 \cdot 3$ & 4.9 & 5.4 & - & - \\
\hline \multicolumn{6}{|l|}{ Language§ } \\
\hline Spanish (\%) & 0 & 0 & 0 & 53 & 0 \\
\hline English (\%) & 100 & 100 & 100 & 47 & 100 \\
\hline
\end{tabular}

*One parent reported age $<25$ years.

†Data on student ethnicity was not collected from students. Estimates reflect 2012 district-level ethnic composition.

$\ddagger$ Teacher grade level is not mutually exclusive.

$\S$ Refers to the language spoken during the interview/focus group.

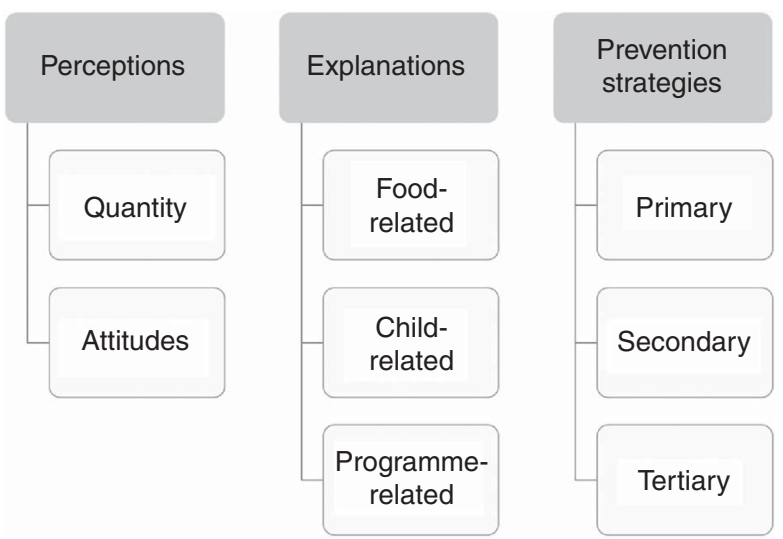

Fig. 1 Food waste-related themes and sub-themes emerging from focus group and interviews with stakeholders (principals, cafeteria managers, teachers, parents and students) from ten elementary schools in a large urban US school district implementing a universal free Breakfast in the Classroom model of the School Breakfast Program

who described its magnitude as: '.. a lot of waste, like I said', 'that it's a lot of waste that shouldn't be waste', 'a tremendous amount of food that's wasted', 'we're just tossing way too much of it' and 'I don't even want to think about how much trash we're making.'

With regard to quantity, the milk meal component was frequently referenced as contributing most substantially to overall food waste. One cafeteria manager explained: ' ... we get a lot more milk back than food.' Teachers agreed that 'The milk goes back - if anything, the milk would be the item that is thrown out the most.' Although few quantified the precise amount of milk waste in their classrooms, one teacher suggested that more than half of cartons offered were discarded as 'The number of milks we've - I have 20, only 21 students right now. But I would say, on the average, we throw away at least 15 milks a day.'

\section{Emotions and attitudes}

Stakeholders who made subjective valuations of food waste in the BIC model expressed negative sentiments, especially towards the absolute magnitude of food waste. Many of these attitudes corresponded to the absolute quantity of waste associated with model implementation. Participants used a variety of disparaging adjectives to describe food waste in the model: '... it's terrible. It's a shame...', 'it's daunting', '... it's wretched' and 'it's ridiculous' among others. These descriptors were reflected in accompanying personal sentiments and emotions: '... I feel bad'..., 'it makes me sick', '... makes me feel real bad' and 'it hurts me to see all that food going to waste'. One parent expressed concern for the long-term implications of food waste: 'It's horrible, we're teaching the kids to throw away their food.' The only positive comments related to food waste mentioned that the elimination of recess as an alternative to breakfast participation may have reduced waste.

\section{Explanations for food waste}

The phenomenon of food waste was attributed to three explanatory factors: (i) food-related; (ii) child-related; and (iii) programme-related. 
Table 3 Selected participant quotes by theme and sub-theme: stakeholders (principals, cafeteria managers, teachers, parents and students) from ten elementary schools in a large urban US school district implementing a universal free Breakfast in the Classroom model of the School Breakfast Program

\begin{tabular}{|c|c|c|c|c|c|c|c|}
\hline \multicolumn{2}{|c|}{ Perceptions } & \multicolumn{3}{|c|}{ Explanations } & \multicolumn{3}{|c|}{ Mitigation } \\
\hline Quantity & Attitudes & Food & Child & Programme & Primary & Secondary & Tertiary \\
\hline $\begin{array}{l}\text { 'It would vary day to } \\
\text { day. There's } \\
\text { some days where } \\
\text { it's - like, nobody } \\
\text { eats it.' (T) }\end{array}$ & $\begin{array}{l}\text { 'And that's just - } \\
\text { it's terrible. It's } \\
\text { a shame, that } \\
\text { it's a lot of } \\
\text { waste that } \\
\text { shouldn't be } \\
\text { waste.' (CM) }\end{array}$ & $\begin{array}{l}\text { 'And sometimes - it's a } \\
\text { waste of food - like } \\
\text { yesterday, the muffin } \\
\text { pretty much goes to } \\
\text { the trash.' (T) }\end{array}$ & $\begin{array}{l}\text { 'But there are sometimes } \\
\text { that they have gone } \\
\text { hungry, because they } \\
\text { just don't like the } \\
\text { choices.' (T) }\end{array}$ & $\begin{array}{l}\text { '... there's no way to } \\
\text { know how many } \\
\text { kids are coming to } \\
\text { school in the } \\
\text { morning...' (CM) }\end{array}$ & $\begin{array}{l}\text { 'Also, I encourage them to } \\
\text { eat because I feel bad, } \\
\text { the tremendous amount } \\
\text { of food that's wasted.' (T) }\end{array}$ & $\begin{array}{l}\text { 'I just put it in the } \\
\text { bin that you have } \\
\text { to save the food, } \\
\text { and then if you } \\
\text { want it, then you } \\
\text { get it there.' (S) }\end{array}$ & $\begin{array}{l}\text { 'An organization to donate } \\
\text { to. And since that is not } \\
\text { worked out, and since } \\
\text { it's a long process, it's } \\
\text { being thrown away.' (CM) }\end{array}$ \\
\hline $\begin{array}{l}\text { 'I have seen whole } \\
\text { trays just } \\
\text { dumped, don't } \\
\text { even touch it.' } \\
\text { (EP) }\end{array}$ & $\begin{array}{l}\text { 'I don't even want } \\
\text { to think about } \\
\text { how much } \\
\text { trash we're } \\
\text { making.' (T) }\end{array}$ & $\begin{array}{l}\text { 'A lot of kids don't like } \\
\text { milk, so sometimes } \\
\text { we do have to throw } \\
\text { some of that milk } \\
\text { away because they } \\
\text { don't drink it.' (FS) }\end{array}$ & $\begin{array}{l}\text { 'Some of them, they'll eat } \\
\text { just a small portion } \\
\text { where they may have } \\
\text { had breakfast at home } \\
\ldots \text { so they'll have a } \\
\text { tendency to throw it } \\
\text { away.' (T) }\end{array}$ & $\begin{array}{l}\text { '... because } \\
\text { remember, if they } \\
\text { take the breakfast, } \\
\text { they're being } \\
\text { checked off. } \\
\text { Regardless of how } \\
\text { much they eat.' }(P)\end{array}$ & $\begin{array}{l}\text { 'And then at the trash, I } \\
\text { don't give them spoons } \\
\text { or a tray, unless they } \\
\text { have a piece of fruit. So } \\
\text { l'm trying to reduce the } \\
\text { amount of trash...' (T) }\end{array}$ & $\begin{array}{l}\text { 'I put it in my } \\
\text { teacher's basket, } \\
\text { what she saves } \\
\text { to bring home.' } \\
\text { (S) }\end{array}$ & $\begin{array}{l}\text { 'One of the parents noticed } \\
\text { that we throw away the } \\
\text { food, and she wanted } \\
\text { the unused food. She } \\
\text { wanted to take it to } \\
\text { someone who's hungry.' } \\
\text { (P) }\end{array}$ \\
\hline $\begin{array}{l}\text { 'They dump it in the } \\
\text { trash can. They } \\
\text { won't even look } \\
\text { at it, they just } \\
\text { dump it.' (EP) }\end{array}$ & $\begin{array}{l}\text { 'It's horrible, } \\
\text { we're teaching } \\
\text { the kids to } \\
\text { throw away } \\
\text { their food.' (T) }\end{array}$ & $\begin{array}{l}\text { '... they were very } \\
\text { excited, very happy to } \\
\text { know that they were } \\
\text { bananas and when we } \\
\text { opened they were all } \\
\text { ripe - over-ripe.' (T) }\end{array}$ & 'I'm not that hungry.' (S) & $\begin{array}{l}\text { 'So, they're always - } \\
\text { seemed like they } \\
\text { were rushing } \\
\text { through the } \\
\text { breakfast. "Hurry, } \\
\text { eat, throw it } \\
\text { away".' (EP) }\end{array}$ & $\begin{array}{l}\text { 'Like, if they were given an } \\
\text { unlimited amount of } \\
\text { time, they might eat } \\
\text { more...' (T) }\end{array}$ & $\begin{array}{l}\text { 'I save it and } \\
\text { sometimes I give } \\
\text { it to my teacher.' } \\
\text { (S) }\end{array}$ & $\begin{array}{l}\text { '... so the parents have } \\
\text { started this thing where } \\
\text { they take the fruit down } \\
\text { to the garden on } \\
\text { Wednesdays and eat it, } \\
\text { or they compost it.' }(P)\end{array}$ \\
\hline $\begin{array}{l}\text { 'And I see a lot of } \\
\text { food that is, you } \\
\text { know, being } \\
\text { wasted.' (EP) }\end{array}$ & 'It's ridiculous.' (T) & $\begin{array}{l}\text { 'The oranges were not - } \\
\text { they couldn't peel } \\
\text { them, it was a } \\
\text { problem.' (T) }\end{array}$ & $\begin{array}{l}\text { 'Sometimes I get full, or I } \\
\text { don't like it'. (S) }\end{array}$ & $\begin{array}{l}\text { '... sometimes they } \\
\text { don't want to eat } \\
\text { that early, because } \\
\text { it's too early.' (EP) }\end{array}$ & $\begin{array}{l}\text { 'I'm wondering, what if } \\
\text { they half-sized the milk } \\
\text {... because they're just } \\
\text { not utilizing it all.' }(P)\end{array}$ & $\begin{array}{l}\text { 'Sometimes I give it } \\
\text { to - I put my on } \\
\text { the teacher's... } \\
\text { basket.' (S) }\end{array}$ & $\begin{array}{l}\text { 'We can't keep it. Like the } \\
\text { burrito, how? How are } \\
\text { we going to keep the } \\
\text { burritos?' (CM) }\end{array}$ \\
\hline $\begin{array}{l}\text { ‘... it's coming } \\
\text { back and didn't } \\
\text { even get } \\
\text { touched.' (CM) }\end{array}$ & $\begin{array}{l}\text { 'It makes me } \\
\text { sick.' (EP) }\end{array}$ & & $\begin{array}{l}\text { '... it's too much for a } \\
\text { kindergartener; but it's } \\
\text { sometimes not enough } \\
\text { for a fourth or fifth } \\
\text { grader.' (EP) }\end{array}$ & $\begin{array}{l}\text { 'Because they don't } \\
\text { give us enough } \\
\text { time.' (S) }\end{array}$ & & $\begin{array}{l}\text { 'But mostly we } \\
\text { return them to } \\
\text { the - to the } \\
\text { cafeteria.' (S) }\end{array}$ & \\
\hline \multirow[t]{2}{*}{$\begin{array}{l}\text { 'How much is being } \\
\text { thrown away?' } \\
\text { 'Minimum over } \\
\text { half.' 'It's huge.' 'I } \\
\text { would say } 65 \% \text { \%.' } \\
\text { 'Probably } 30 \% \text {.' } \\
\text { (T) }\end{array}$} & $\begin{array}{l}\text { '... the biggest } \\
\text { problem that } \\
\text { l've had is with } \\
\text { the waste.' }(P)\end{array}$ & & & & & $\begin{array}{l}\text { 'So what we can } \\
\text { save, we do, if it's } \\
\text { an orange, or } \\
\text { something that } \\
\text { can be saved, we } \\
\text { do.' (CM) }\end{array}$ & \\
\hline & $\begin{array}{l}\text { 'We're just } \\
\text { tossing way } \\
\text { too much.' (P) } \\
\text { 'I couldn't bear to } \\
\text { throw it.' (T) }\end{array}$ & & & & & & \\
\hline
\end{tabular}

P, principal; CM, cafeteria manager; T, teacher; EP, English-speaking parent; S, student. 


\section{Food-related}

Comments associating food attributes with waste related primarily to its accessibility and perishability.

Accessibility. Some foods were reportedly difficult for children to access. The motor skills required to consume specific foods in a timely fashion were referenced as reasons children are not able to finish it within the allotted meal time. This explanation was particularly relevant to fruit. As one teacher explained: 'They like the oranges but it takes a toll ... we don't have time to cut the fruit for them like the preps do...'. Another parent questioning the dexterity of young children substantiated: 'Imagine a little kid - a kindergarten kid having an apple in the morning ... he's not going to have to have time to eat that apple. Or, if it's an orange - you have to peel it, because they're not, like, in the little bag or anything. They have to do it themselves...'

Perishability. With regard to spoilage, stakeholders mentioned both perishable and packaged foods received in expired or deteriorated conditions on multiple occasions. 'We've had a few times where we've had expired food in our breakfasts', one teacher recalled. Foods in such conditions were cited as provoking participant scepticism and mass disposal. As one teacher explained: 'One of the kids will notice, and then everyone looks, and then - they won't eat it, they'll throw it away. Even if it's a day late, they won't, they're not eating it.' In contrast to savable items, hot foods were referenced regarding waste susceptibility: 'But if it's something that needs to be hot and served hot, and it'll go bad ... you know, then it gets thrown away.' Aside from hot and perishable items, spoiled food items in the grain meal component had been encountered on more than one instance, and milk and fruit perishability was underscored. One teacher noted that 'Any milk that's not touched is thrown away', citing programme food safety standards. The perishability of fruit and its tendency to over-ripen were also noted in association with its disposal. Recounting a conversation with her daughter, one parent commented: '... she'll tell me, "Oh, Mom, like, the bananas were ugly today, so I didn't eat".'

\section{Child-related}

Intrapersonal explanations for food waste varied across students. Two main areas of comment included taste preferences and satiation, which related to disliking of specific foods/food groups and self-regulation of food intake, respectively.

Taste preferences. With regard to student acceptance of SBP food, some made overall assessments of students' acceptance of foods served in the programme, as one parent generalized: 'Because the food is not good. They don't like the food that they're served.' A student similarly explained '...the food, it doesn't really taste that good.' The novelty and healthfulness (particularly sugar content) of SBP food were more precisely pinpointed by many as a factor contributing to their rejection. Some of the menu changes that coincided with BIC implementation were attributable to the BIC model while others were in response to district initiatives and federal standards. For example, this was the first year in which the district no longer offered chocolate milk and various new grain items were piloted. As one student commented, 'I liked it before when it was chocolate.' Respondents associated specific menu items with student dissatisfaction and contemporaneous disposal. For example, one teacher described: 'It would vary day to day. There [are] some days where it's - like the oatmeal bar day, it's like, nobody eats it.' A student confirmed: 'And the oatmeal bar. The oatmeal bar. I don't like it.' Alternatively, participants reported milk waste as subject to daily disposal, perceiving its waste as resulting from children's general distaste for it. As a cafeteria manager explained: '... A lot of kids don't like milk, so sometimes we do have to throw some of that milk away because they don't drink it.' Another cafeteria manager attributed students' rejection to a distaste for plain milk specifically: '.. They only have white milk. ... that's why I think some of the kids don't like to drink their milk, because it's just plain - just white milk and before, they had chocolate milk, and when they had chocolate milk, they were crazy about that milk. They love that milk. Yes.' Whereas in the cafeteria, milk that children refused could be reserved, once offered in the classroom, food safety standards required that it be disposed.

While programme rules dictate the number of food items a child must select to qualify as a reimbursable meal, the student ultimately decides how much of each food item to consume, making individual taste preferences and appetite strong determinants of waste: 'If I don't like it, then I just throw it away', one child reported. A teacher confirmed 'And then the days that they don't like it, they don't - they don't eat', referencing variations in daily consumption patterns. Aware of this variability, parents expressed concern about children's SBP consumption patterns.

Satiation. Children also referenced satiation as a reason for not eating or not consuming all of their food. As one student recalled, 'Because I was full, and I didn't want to eat no more.' This physiological response was attributed to uniform portion sizes across $\mathrm{K}-5$ grade levels, which may be inappropriately large for younger children, and to eating at home before school. Parents confirmed this practice, as one recounted: 'I also give them breakfast at home because there are certain things they don't like, so I prefer for them to eat well at home, and then if they're still hungry, they can finish eating [at school].'

\section{Programme-related}

Logistical and structural characteristics of the programme discussed as contributors to food waste included meal duration, policies (including reimbursement and OVS rules) and coordination. 
Duration. Time allotted for eating, which is specified by the district as $10 \mathrm{~min}$ but varies somewhat by classroom, was frequently cited as restricting student consumption. As one parent observed in the classroom: "And the teacher would say, "Okay, five minutes up. Clean up." And then all students will pick up their trays and dump it. Either they eat or not, but they have to clean up.' Another commented on his/ her child's feedback: '... my child, he's always telling me he don't have enough time to eat ... he could only eat so little, and they told him to throw it away right away.' A student expressed: 'Sometimes I feel like it's not enough time', and a teacher confirmed that 'I think a lot of the food gets thrown away because they just don't have enough time to eat it.'

Food service policies. It was also apparent that SBP policies, including reimbursement rules, OVS policy and food safety standards, influenced the quantity of food waste. As one principal recognized: 'It's just like, because there is a lot of - and because it's very structured, and we have a lot of regulations to follow, and you know, it's just that, we do see a lot of milk going to waste, and stuff like that, you know.' A student alluded to the OVS policy as an explanation for waste: 'Sometimes because I don't really like it. Like, if I don't like the food, but I still grab it to drink my milk, and all of that.' Finally, a food service manager referred to both reimbursement requirement and food safety as contributors to waste: 'If your kid doesn't want the milk, they have to open it up and throw it down the sink themselves, to say they've got a complete meal. That's not happening. I'm getting the milk back, so we have to throw it away.'

Coordination. Lack of communication between food service and classroom staff in accounting for day-to-day variation in attendance and participation was noted as a reason for classroom supply exceeding demand. As one cafeteria manager explained: '... we get these rosters, and we know how many kids have it in the classroom, and it's what we serve. It's not because the kids are going to eat it. That's only because - it's on the roster.' A second aspect related to menu awareness and schools' adherence to published menus. As one parent commented: '... you see what's on the menu, but it's not enough for all the kids, and they give them something else, and sometimes they don't like what they're supposedly going to get. Or they might like it, but when they end up getting something else, they'd rather not eat and they leave it and throw it away.' Therefore, menu deviation could increase food waste if children are unexpectedly served less favourable items, or if they eat at home to safeguard against uncertainty and are consequently less hungry. In fact, eating at home before school was recognized as serving this purpose: ' $\ldots$ if they don't know what they're going to give, they've already ate or drank something before they go to the class, just in case they don't like what there is in the classroom.'

\section{Strategies to mitigate food waste}

Reported efforts and suggestions to mitigate food waste in the programme corresponded with the aforementioned attitudes towards and explanations for waste. These included actions to reduce food waste (primary prevention), reuse food (secondary prevention) and minimize its impact (tertiary prevention). Some had already been attempted or adopted while others were identified as possible means.

Primary prevention. Primary prevention efforts aimed to increase consumption of food during the breakfast period. These measures responded to children's reluctance to consume the food, its inaccessibility, time constraints and satiation. With regard to access, one teacher recounted: '... I cut every single piece of fruit because I know that they'll eat it. Otherwise, they'll take a few bites and throw it away.' However, resource constraints were cited as an adoption barrier, as another teacher suggested: 'Maybe if we had extra staff, yeah. Maybe one extra morning person, yeah, to do the fruit alone and to help out, yeah.' Likewise, despite its potential, pre-cut, packaged fruit was offered as a solution but was reported as less palatable to students. Teachers also commented on efforts to encourage students to consume food, employing games and persuasion tactics in their pursuits to prevent waste. One teacher explained: 'I get them to drink their milk, because they turn it into a game. That's the only way I can get them to drink it...'. However, other teachers recognized its limitations, as one remarked: 'They're not even drinking their milk, and I'm really pushing, you need some protein to start the day.' Considering future options, a principal posited: 'I'm wondering, what if they half-sized the milk ... because they're just not utilizing it all...'. Other participants corroborated this suggestion, commenting on the quantity of food being too great, especially for younger students.

Secondary prevention. Teachers and students reported efforts to prevent disposal of food during the breakfast period, most commonly saving it for future consumption. As one student reported: 'I just put it in the - the bin that you have to save the food, and then if you want it, then you get it there.' A teacher confirmed: 'So what we can save, we do, if it's an orange, or something that can be saved, we do.' With regard to following disposal rules, one principal commented: 'It's really hard - you don't want to tell a kid no, no, no, you got to get rid of that, guess what, we're going to throw it away, but you can't have it for recess. That's tough. I don't want kids to not have something.' Regardless of its effectiveness, food saving was noted as strategy that cannot be applied to all foods: '... if it's something that needs to be hot and served hot, and it'll go bad, or dairy or something like that, you know, then it gets thrown away.'

Tertiary prevention. Finally, the possibility of diverting leftover food for productive uses was recognized. Composting portions of uneaten food items and donating unopened food items were not widely recognized but were mentioned as strategies to address food that could not be preserved. A principal noted that, 'One of the 
parents noticed that we throw away the food, and she wanted the unused food. She wanted to take it to someone who's hungry. So that was another concern: basically, what are we doing about the food that isn't eaten?' A principal referred to one grass-roots composting effort at his/her school: '. . the biggest problem that I've had is with the waste, so the parents have started this thing where they take the fruit down to the garden on Wednesdays and eat it, or they compost it.'

\section{Discussion}

Stakeholders in a large, urban school district implementing a universal free BIC model of the SBP recognized food waste as a problem, reported myriad contributing factors, and have considered and employed multiple and diverse mitigation strategies. These findings have important implications for developing and implementing potential mitigation strategies on a broader scale.

While parsed into distinct themes for the current analysis, it is evident that explanations for food waste interact on multiple levels and, together with perceptions of food waste, inform mitigation efforts and ideas (Fig. 2). For example, the inaccessibility of fruit interacted with programme duration, motivating some teachers to cut up fruit out of concern for children's nutrient consumption, loss of instructional time and unease about food waste. Recognizing and targeting these interacting contributions to waste through multicomponent interventions will enhance their efficiency. For example, since younger children are likely to waste more food $^{(1,31)}$, serving smaller portion sizes and providing time for eating may act synergistically. Once identified, best practices should be shared across schools.

Findings from the NSLP offer several potential strategies to reduce waste ${ }^{(8)}$ : extending eating time ${ }^{(23)}$, increasing the variety of offerings ${ }^{(24,47)}$, serving lunch after recess ${ }^{(21,22)}$, improving meal quality ${ }^{(16)}$, allowing children to serve themselves ${ }^{(19,20)}$ and serving fruit in ready-to-eat forms ${ }^{(25,48)}$.

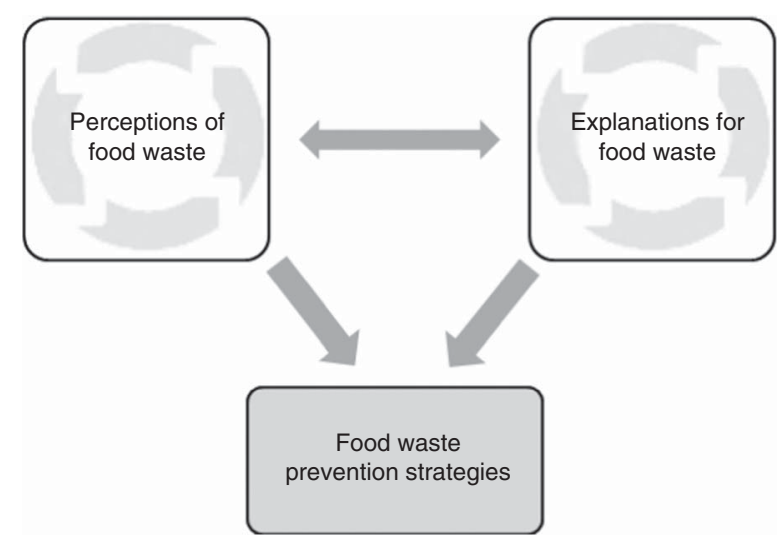

Fig. 2 Interacting perceptions of and explanations for food waste drove existing and suggested prevention strategies
However, because the SBP operates under unique scheduling and service constraints, the transferability of these strategies is unknown. Even within the SBP, each delivery model, further differentiated by cost structure, faces unique waste challenges. Since the present study took place in a single district implementing a universal free BIC model, results may not generalize to other BIC models and/or to other SBP programmes. Our findings suggest that, compared with when breakfast was served in the cafeteria, stakeholders perceive waste per student to have decreased, despite general agreement that the total amount of waste had increased as a result of increased BIC SBP participation.

Based on behaviours and suggested strategies for mitigating food waste reported, prevention efforts at each level could aid in reducing waste: primary prevention efforts, such as changes to the menu, food service policy, food safety management and/or improved programme coordination (e.g. accurate attendance/participation records, tailored meal size/composition and menu fidelity); secondary prevention efforts aimed at storing intact food for later consumption; and tertiary prevention efforts aimed at repurposing leftover food (e.g. donating and composting) may reduce waste and lessen its nutritional and environmental impact.

Addressing food waste in a programme that reaches children at heightened risk of food insecurity and obesity is a complicated issue. For example, actively encouraging students to eat food was met with questionable success by teachers and may have the unintended effect of overconsumption. The aim of mitigation efforts must not jeopardize children's health and must recognize the infeasibility of achieving zero waste. It is also essential to acknowledge the resource limitations schools face; the financial impact of waste reduction strategies must be evaluated prior to implementation, as school food authorities must maintain a delicate balance of competing objectives to break even ${ }^{(49)}$ and may be reluctant to adopt tenuous strategies. In light of these context-specific waste reduction challenges, successful approaches applied in other realms may not be effective or viable in public school settings. Therefore, pilot testing of waste mitigation efforts is needed prior to scale-up and solutions that synergistically optimize nutrient intake while reducing food waste and minimizing costs incurred to schools must be identified.

\section{Priority food groups}

Two meal components received the most attention for their perceived contribution to food waste: fruit and milk. Previous findings add validity to these reports. Observational estimates of plate waste in a BIC SBP in Milwaukee found that only $55 \%$ of milk and $57 \%$ of fruit were fully consumed $^{(31)}$. The single other breakfast-specific plate waste study observationally estimated waste in a summer breakfast programme; milk and fruit were wasted in the highest proportions at $38 \%$ and $31 \%$, respectively ${ }^{(50)}$. Fruit and milk waste is important to address due to the high cost 
and environmental impact ${ }^{(51-55)}$, respectively, as well as low rates of consumption and nutritional importance among school-age children ${ }^{(56-58)}$.

\section{Fruit}

Finding effective means of minimizing fruit waste is crucial from economic, nutritional and environmental perspectives. The majority of children in the USA fail to meet national guidelines for fruit consumption by considerable margins $^{(57,59)}$. Beginning in 2014, schools will be required to double the quantity of fruit offered in the SBP from one-half to one cup, and students will be required to take one-half cup. While participants in our study reported that fruit was generally well liked, its perishability and inaccessibility were noted as consumption barriers and serving pre-packaged, cut fruit compromised acceptability. Previous findings demonstrate that increasing the variety of produce offered to students within a meal may increase fruit consumption and reduce waste by increasing choice ${ }^{(8,24,60-63)}$. The quality of fresh fruit may also affect consumption by altering its palatability and children may be especially sensitive to sensory characteristics of fruit ${ }^{(64)}$. Therefore, exploring other ways of making fruit more convenient and palatable could aid in improving acceptance.

\section{Milk}

Although milk is required to be offered to every student at every school meal, the majority of school-age children fail to meet dairy consumption recommendations ${ }^{(56,65)}$. In our study, milk waste was attributed to perishability and students' distaste for the beverage. Therefore, identifying innovative strategies to increase student liking and/or reduce its perishability may reduce waste ${ }^{(59)}$. While improving the nutritional profile of the milk meal component, nutrition standards limiting fat content may have had the unintended consequences of decreasing consumption and increasing waste $^{(47,66,67)}$. With more than half of US children expected to be of Hispanic, Black or Asian decent by 2019 ${ }^{(68)}$, populations at increased risk for lactose malabsorption and intolerance ${ }^{(69-71)}$, offering non-dairy milks may increase acceptability. At the same time, leaders in the field have questioned dairy intake recommendations ${ }^{(72)}$.

\section{Strengths and limitations}

The present analysis has several strengths. To the authors' knowledge, the current study is the first to report on stakeholders' perceptions of food waste in the SBP. By including a comprehensive participant population consisting of school principals, teachers, students and cafeteria managers, the study captured multiple and diverse perspectives on the issue. Because the district serves a high percentage of underserved children, findings have implications for those at greatest need. Furthermore, inclusion of English- and Spanish-speaking parents expands the generalizability of findings. Finally, the study is timely in terms of its relevance to breakfast programme participation trends and national food waste reduction efforts. The congruence between the perceived causes for food waste and the proposed mitigating factors provides promising avenues for both research and programme implementation.

Several limitations of the study are noteworthy. First, although efforts were made to achieve district representativeness, the study relied upon a non-random sample, which may limit its external validity. Furthermore, the study occurred in a large, urban district, which may limit the generalizability of results to similar districts. Second, since the study schools had recently adopted the BIC model, food waste may have been greater and more variable than might be expected following adjustment. Finally, the analysis is embedded within a larger qualitative exploration of stakeholder perceptions of BIC; while questions in the data collection instruments related specifically to food waste, additional and more focused questions and probes have more fully captured the phenomenon's complexity, including detail about its occurrence and mitigation strategies. More content pertaining to food waste would also have permitted us to determine whether perceptions differed by demographics (e.g. English and Spanish speakers) within respondent groups.

\section{Future directions}

In light of these limitations and the dearth of previous studies, further research is needed to comprehensively assess food waste in the SBP. A thorough understanding of the problem will lead to enhanced intervention design and implementation. These strategies will need to undergo process and outcome evaluations, and be scaled up appropriately. With the US Department of Agriculture's 2013 Food Challenge committed to funding studies estimating plate waste and evaluating innovative strategies to reduce it, while providing guidance, technical assistance, training, resources and support to schools ${ }^{(15)}$, it is expected that further inquiry will build upon our findings towards improving the environmental, economic and nutrition impacts of food waste in the SBP.

\section{Acknowledgements}

Acknowledgements: The authors would like to thank Su Pak, Hayden Ross, Emily Rak, Allison Knott, Nicole Lanoue and Vanessa Lynskey for their assistance with data collection; Firas Shalabi for his contribution to data analysis; Dr Shanti Sharma for her contribution to study design; Dr Sara Folta for her consultation services and contributions to study design and data analysis; and Megan Halmo and Katie Smith for their contributions to study design, data collection and data analysis. Finally, they would like to express gratitude for the contributions of school the district staff and study participants, without whom this research would not have been possible. 
Financial support: This study was commissioned by ChildObesity180, a multi-sector group of senior-level national leaders working together to create a coordinated and integrated set of strategies to reverse the trend of childhood obesity. Strategic funding for ChildObesity180 is provided by the Robert Wood Johnson Foundation and The JPB Foundation. Neither Foundation played any role in the design, analysis or writing of this article. Conflict of interest: None. Author contributions: S.A.B. contributed to study design and data analysis, and led the writing of the manuscript; H.D.C. contributed to data collection and analysis; N.M. contributed to data analysis; S.A.-F. contributed to the writing and revising of the manuscript; C.D.E. led the project as Principal Investigator, overseeing all stages of study design, data collection and analysis. All authors contributed to the manuscript content and revisions and have read and approved the final version. Etbics of buman subject participation: The study was conducted according to the guidelines laid down in the Declaration of Helsinki, and all procedures involving human subjects were approved by the Tufts University Institutional Review Board and by the school district's Committee for External Research Review Chair. Written and/or verbal informed consent was obtained from all adult participants and informed assent was obtained from children.

\section{References}

1. Buzby JC, Wells HF \& Hyman J (2014) The Estimated Amount, Value, and Calories of Postharvest Food Losses at the Retail and Consumer Levels in the United States. Economic Information Bulletin no. EIB-121. Washington, DC: US Department of Agriculture, Economic Research Service; available at http://www.ers.usda.gov/publications/ eib-economic-information-bulletin/eib121.aspx

2. Lipinski B, Hanson C, Lomax J et al. (2013) Reducing Food Waste and Loss. Working Paper, Installment 2 of 'Creating a Sustainable Food Future'. Washington, DC: World Resources Institute; available at http://www.wri.org/sites/default/ files/reducing_food_loss_and_waste.pdf

3. Food and Agriculture Organization of the United Nations (2013) Food Waste Footprint: Impacts on Natural Resources. Summary Report. Rome: FAO; available at http://www.fao. org/docrep/018/i3347e/i3347e.pdf

4. Gunders D (2012) Wasted: How America Is Losing Up to 40 Percent of Its Food from Farm to Fork to Landfill. NRDC Issue Paper no. IP-12-06-B. New York: National Resources Defense Council; available at http://www.nrdc.org/food/ files/wasted-food-IP.pdf

5. US Department of Agriculture, Economic Research Service (2013) Child Nutrition Programs: School Breakfast Program. http://www.ers.usda.gov/topics/food-nutrition-assistance/ child-nutrition-programs/school-breakfast-program.aspx\#. UY6CerXvvfI (accessed December 2014).

6. US Department of Agriculture, Economic Research Service (2013) Child Nutrition Programs: National School Lunch Program. http://www.ers.usda.gov/topics/food-nutritionassistance/child-nutrition-programs/national-school-lunchprogram.aspx\#.Uo-II_nZhco (accessed December 2014).

7. US Department of Agriculture, Food and Nutrition Service (2013) National School Lunch Program and School
Breakfast Program: Nutrition Standards for All Foods Sold in School as Required by the Healthy, Hunger-Free Kids Act of 2010; 7 CFR Parts 210 and 220. Interim Final Rule. Fed Reg 78, 39067-39120; available at http://www.fns.usda.gov/ sites/default/files/2013-15249_0.pdf

8. Buzby J \& Guthrie J (2002) Plate Waste in School Nutrition Programs Final Report to Congress. Electronic Publications from the Food Assistance \& Nutrition Research Program no. E-FAN-02-009. Washington, DC: US Department of Agriculture, Food and Nutrition Service; available at http:// www.ers.usda.gov/media/887982/efan02009.pdf

9. Franklin B, Jones A, Love D et al. (2012) Exploring mediators of food insecurity and obesity: a review of recent literature. J Community Health 37, 253-264.

10. Kuku O, Garasky S \& Gundersen C (2012) The relationship between childhood obesity and food insecurity: a nonparametric analysis. Appl Econ 44, 2667-2677.

11. Ryu JH \& Bartfeld JS (2012) Household food insecurity during childhood and subsequent health status: The Early Childhood Longitudinal Study - Kindergarten Cohort. Am J Public Health 102, e50-e55.

12. Eisenmann JC, Gundersen C, Lohman BJ et al. (2011) Is food insecurity related to overweight and obesity in children and adolescents? A summary of studies, 1995-2009. Obes Rev 12, e73-e83.

13. Larson NI \& Story MT (2011) Food insecurity and weight status among US children and families: a review of the literature. Am J Prev Med 40, 166-173.

14. Martin KS \& Ferris AM (2007) Food insecurity and gender are risk factors for obesity. J Nutr Educ Behav 39, 31-36.

15. Eckhouse S (2013) The US Food Waste Challenge. http:// www.ncsl.org/documents/statefed/SarahEckhouseUSDA.pdf (accessed March 2014).

16. Cohen JF, Richardson S, Austin SB et al. (2013) School lunch waste among middle school students: nutrients consumed and costs. Am J Prev Med 44, 114-121.

17. Smith SL \& Cunningham-Sabo L (2014) Food choice, plate waste and nutrient intake of elementary- and middle-school students participating in the US National School Lunch Program. Public Health Nutr 17, 1255-1263.

18. Hollingsworth MD, Shanklin CW \& Cross EW (1995) Waste stream analyses in seven selected school food service operations. Sch Food Serv Res Rev 19, 81-87.

19. Broussard S \& Fournet R (1996) A reevaluation of the use of a self-service fruit and vegetable bar on consumption and plate waste. J Am Diet Assoc 96, A66.

20. Kerfoot BA \& Fournet RM (1996) Evaluation of the use of a self-service fruit and vegetable bar on the consumption and plate waste. J Am Diet Assoc 96, A10.

21. Getlinger M, Laughlin C, Bell E et al. (1996) Food waste is reduced when elementary-school children have recess before lunch. J Am Diet Assoc 96, 906-908.

22. Bergman E, Buergel N, Englund T et al. (2004) Elementary students eat more and waste less when recess is scheduled before lunch. J Am Diet Assoc 104, 45.

23. Bergman EA, Buergel N, Englund $\mathrm{T}$ et al. (2004) The relationship between the length of the lunch period and nutrient consumption in the elementary school lunch setting. J Child Nutr Manage 28, issue 2, 1-10.

24. Adams MA, Pelletier RL, Zive MM et al. (2005) Salad bars and fruit and vegetable consumption in elementary schools: a plate waste study. J Am Diet Assoc 105, 1789-1792.

25. Marlette MA, Templeton SB \& Panemangalore M (2005) Food type, food preparation, and competitive food purchases impact school lunch plate waste by sixth-grade students. J Am Diet Assoc 105, 1779-1782.

26. Reger C, Clesi A, Nicklas TA et al. (1995) Estimation of plate waste of school lunches served to children of low socioeconomic status. J Am Diet Assoc 95, A38. 
27. Reger C, O'Neil CE, Nicklas TA et al. (1996) Plate waste of school lunches served to children in a low-socioeconomic elementary school in south Louisiana. Sch Food Serv Res Rev 20, Suppl., 13-19.

28. Just D \& Price J (2013) Default options, incentives and food choices: evidence from elementary-school children. Public Health Nutr 16, 2281-2288.

29. McLaughlin JE, Bernstein LS, Crepinsek MK et al. (2004) Evaluation of the School Breakfast Program Pilot Project: Executive Summary. Alexandria, VA: US Department of Agriculture, Food and Nutrition Service; available at http://www.fns.usda.gov/sites/default/files/ SBPPExecSum.pdf

30. Bernstein LS, McLaughlin JE, Crepinsek MK et al. (2004) Evaluation of the School Breakfast Program Pilot Project: Final Report. Nutrition Assistance Program Report Series no. CN-04-SBP. Alexandria, VA: US Department of Agriculture, Food and Nutrition Service; available at http://permanent. access.gpo.gov/lps100583/www.fns.usda.gov/oane/menu/ Published/CNP/FILES/SBPPFinal.pdf

31. Tran C (2009) An assessment of plate waste within Milwaukee public schools' universal free breakfast-in-theclassroom. FEBS J 280, 3482-3483.

32. US Department of Agriculture, Food and Nutrition Service (2014) Child Nutrition Tables. National Level Annual Summary Tables: FY 1969-2013. School Breakfast: Participation and Meals Served. http://www.fns.usda.gov/pd/ child-nutrition-tables (accessed October 2014).

33. Food and Nutrition Service, US Department of Agriculture (2013) National school lunch program and school breakfast program: eliminating applications through community eligibility as required by the Healthy, Hunger-Free Kids Act of 2010. Fed Reg 78, 65890.

34. Hewins J \& Burke M (2014) School Breakfast Scorecard: 2012-2013 School Year. Washington, DC: Food Resource and Action Center.

35. US Department of Agriculture, Food and Nutrition Service (2012) Nutrition standards in the National School Lunch and School Breakfast Programs. Final rule. Fed Reg 77, 4088-4167.

36. US Department of Agriculture, Food and Nutrition Service (2012) The School Breakfast Program. http://www.fns.usda. gov/sites/default/files/SBPfactsheet.pdf (accessed December 2014).

37. Rampersaud GC, Pereira MA, Girard BL et al. (2005) Breakfast habits, nutritional status, body weight, and academic performance in children and adolescents. $J$ Am Diet Assoc 105, 743-760.

38. Hoyland A, Dye L \& Lawton CL (2009) A systematic review of the effect of breakfast on the cognitive performance of children and adolescents. Nutr Res Rev 22, 220-243.

39. Crepinsek MK, Singh A, Bernstein LS et al. (2006) Dietary effects of universal-free school breakfast: findings from the evaluation of the School Breakfast Program Pilot Project. I Am Diet Assoc 106, 1796-1803.

40. Bailey-Davis L, Virus A, McCoy TA et al. (2013) Middle school student and parent perceptions of Governmentsponsored free school breakfast and consumption: a qualitative inquiry in an urban setting. J Acad Nutr Diet 113, 251-257.

41. Creighton LS (2012) Stakeholder engagement for successful breakfast in the classroom implementation. J Sch Health 82, 496-498.

42. Imberman SA \& Kugler AD (2012) The Effect of Providing Breakfast on Student Performance: Evidence from an In-Class Breakfast Program. NBER Working Paper no. 17720. Cambridge, MA: National Bureau of Economic Research.

43. Van Wye G, Seoh H, Adjoian T et al. (2013) Evaluation of the New York City breakfast in the classroom program. $A m J$ Public Health 103, e59-e64.
44. Nanney MS, Olaleye TM, Wang Q et al. (2011) A pilot study to expand the school breakfast program in one middle school. Transl Behav Med 1, 436-442.

45. Gibbs GR (2008) Analysing Qualitative Data. London: SAGE Publications Ltd.

46. Boyatzis RE (1998) Transforming Qualitative Information: Thematic Analysis and Code Development. Thousand Oaks, CA: SAGE Publications, Inc.

47. Guthrie HA (1977) Effect of a flavored milk option in a school lunch program. J Am Diet Assoc 71, 35-40.

48. Wansink B, Just DR, Hanks AS et al. (2013) Pre-sliced fruit in school cafeterias: children's selection and intake. Am J Prev Med 44, 477-480

49. Wilde P (2013) Food Policy in the United States: An Introduction. New York: Routledge.

50. Gordon A, Briefel R, Needels $\mathrm{K}$ et al. (2003) Feeding Low-Income Children When School Is Out: The Summer Food Service Program Final Report. Princeton, NJ: Mathematica Policy Research, Inc.

51. Drewnowski A (2010) The cost of US foods as related to their nutritive value. Am J Clin Nutr 92, 1181-1188.

52. Garnett $\mathrm{T}$ (2011) Where are the best opportunities for reducing greenhouse gas emissions in the food system? Food Policy 36, Suppl. 1, S23-S32.

53. Reijnders L \& Soret S (2003) Quantification of the environmental impact of different dietary protein choices. Am J Clin Nutr 78, 664-668.

54. Matlock M, Thoma G, Cummings E et al. (2013) Geospatial analysis of potential water use, water stress, and eutrophication impacts from US dairy production. Int Dairy J 31, Suppl. 1, S78-S90.

55. Thoma G, Popp J, Nutter D et al. (2013) Greenhouse gas emissions from milk production and consumption in the United States: a cradle-to-grave life cycle assessment circa 2008. Int Dairy J 31, Suppl. 1, S3-S14.

56. Kit BK, Carroll MD \& Ogden CL (2011) Low-fat milk consumption among children and adolescents in the United States, 2007-2008. NCHS Data Brief issue 75, 1-8.

57. Lorson BA, Melgar-Quinonez H \& Taylor CA (2009) Correlates of fruit and vegetable intakes in US children. $\mathrm{JAm}$ Diet Assoc 109, 474-478.

58. Gao X, Wilde PE, Lichtenstein AH et al. (2006) Meeting adequate intake for dietary calcium without dairy foods in adolescents aged 9 to 18 years (National Health and Nutrition Examination Survey 2001-2002). J Am Diet Assoc 106, 1759-1765.

59. US Department of Agriculture \& US Department of Health and Human Services (2010) Dietary Guidelines for Americans, 2010, 7th ed. Washington, DC: US Government Printing Office; available at http://www.health.gov/ dietaryguidelines/dga2010/dietaryguidelines2010.pdf

60. Perry CL, Bishop DB, Taylor GL et al. (2004) A randomized school trial of environmental strategies to encourage fruit and vegetable consumption among children. Health Educ Behav 31, 65-76.

61. Hanks AS, Just DR \& Wansink B (2012) Trigger foods: the influence of 'irrelevant' alternatives in school lunchrooms. Agric Resour Econ Rev 41, 114-123.

62. Guthrie JF \& Buzby JC (2002) Several strategies may lower plate waste in school feeding programs. Food Rev $\mathbf{2 5}$, 36-42.

63. Hakim SM \& Meissen G (2013) Increasing consumption of fruits and vegetables in the school cafeteria: the influence of active choice. J Health Care Poor Underserved 24, 145-157.

64. Rico D, Martãn-Diana AB, Barat JM et al. (2007) Extending and measuring the quality of fresh-cut fruit and vegetables: a review. Trends Food Sci Technol 18, 373-386.

65. Mangano KM, Walsh SJ, Insogna KL et al. (2011) Calcium intake in the United States from dietary and supplemental sources across adult age groups: new 
estimates from the National Health and Nutrition Examination Survey 2003-2006. J Am Diet Assoc 111, 687-695.

66. Rafferty K, Zipay D, Patey C et al. (2008) Milk enhancements improve milk consumption and increase meal participation in the NSLP: the school milk pilot test. $J$ Child Nutr Manage 33, issue 2; available at http://www.schoolnutrition.org/ 5-News-and-Publications/4-The-Journal-of-Child-Nutritionand-Management/Fall-2009/Volume-33,-Issue-2,-Fall-2009Rafferty;-Zipay;-Patey;-Meye/

67. Nicklas TA, O'Neil CE \& Fulgoni VL (2013) The nutritional role of flavored and white milk in the diets of children. J Sch Health 83, 728-733.

68. Children's Defense Fund (2014) The State of America's Children ${ }^{\circledR} 2014$ Report. Washington, DC: Children's Defense Fund.
69. Scrimshaw NS \& Murray EB (1988) The acceptability of milk and milk products in populations with a high prevalence of lactose intolerance. Am J Clin Nutr 48, $1079-1159$.

70. Lomer MC, Parkes GC \& Sanderson JD (2008) Review article: lactose intolerance in clinical practice - myths and realities. Aliment Pharmacol Ther 27, 93-103.

71. Suchy FJ, Brannon PM, Carpenter TO et al. (2010) NIH consensus development conference statement: lactose intolerance and health. NIH Consens State Sci Statements 27(2), 1-27.

72. Ludwig DS \& Willett WC (2013) Three daily servings of reduced-fat milk: an evidence-based recommendation? JAMA Pediatr 167, 788-789. 